\title{
もみ殼・稲わらの湿式酸化による酶酸の生成*
}

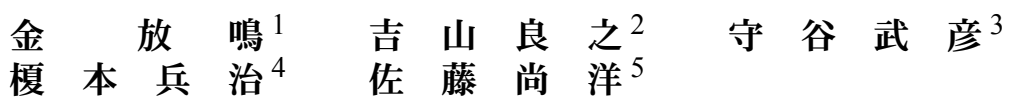

\section{Production of Acetic Acid by Wet Oxidation of Rice Hull and Straw}

by Fangming JIN ${ }^{\mathrm{a}}$, Yoshiyuki YOSHIYAMA ${ }^{\mathrm{b}}$, Takehiko MORIYA ${ }^{\mathrm{c}}$,

Heiji ENOMOTO ${ }^{\mathrm{a}}$ and Naohiro SATO ${ }^{\mathrm{d}}$

a. Department of Geoscience and Technology, Graduate School of Engineering, Tohoku University,

Aoba-ku, Sendai 980-8579, Japan

b. Graduate Student, Department of Geoscience and Technology, Tohoku University

c. Research and Development Center, Tohoku Electric Power Co., Inc., Aoba-ku, Sendai 981-0952, Japan

d. Industrial Technology Institute, Miyagi Prefectural Government, Izumi-ku, Sendai 981-3206, Japan

Rice hull and straw were oxidized at temperatures in supercritical and subcritical water region to produce acetic acid by wet oxidation.

Results showed that a high concentration of acetic acid may be obtained by controlling oxidation conditions. The highest acetic acid yield was about $14 \%$ (TOC/TOC) of the starting materials, which is almost the same as that in the case of oxidation of food wastes. It was also found that there exists a large amount of other low molecular weigh carboxylic acids than acetic acid as residual intermediate products. It seems that the additional yield of acetic acid is hardly obtained from further oxidation of residual low molecular weigh carboxylic acids since the concentration of formic and oxalic acids, which are incapable of producing acetic acid, is relatively high among them. However, the purity of acetic acid in the solution after reaction can be increased easily by increasing the reaction temperature or reaction time, because other residual low molecular weigh carboxylic acids were oxidized much more easily than acetic acid.

No significant difference in residual intermediate products and TOC decomposition was found when changing the reaction temperature from subcritical to supercritical water region over the critical point of water.

KEY WORDS : Acetic Acid, Supercritical Water, Subcritical Water, Wet Oxidation, Rice Hull, Rice Straw

\section{1.は じめに}

有機廃棄物の焼却処理はそれに伴うさまざまな環境負荷が大き いことなどから，再利用・資源化と新たな減量化処理方法の開発 が急務となっている。そのため，筆者らは，蝔房生ごみに代表さ れる高含水率有機廃棄物の超臨界水湿式酸化に関する研究を行っ

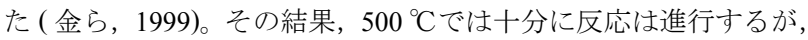
$400{ }^{\circ} \mathrm{C}$ 程度の温度では比較的安定な中間生成物として多量の酶酸 が残存することが分かった。この結果を踏まえて，さらに，筆者 らはこの酢酸を分解せずに，逆に積極的に生成させ，環境負荷の 少ない酶酸カルシウム/マグネシウム路面凍結抑制剂 (Calcium/ Magnesium Acetate, CMA) として利用する新たな酢酸の有効利用 方法について検討した (金ら，2000)。

CMA は 1970 年，アメリカ連邦道路局が中心となって塩化物薬 剤の代替品として開発された環境に優しい路面凍結抑制剂である (Chollar, 1984 ; Gekas and Zhang,1989 ; Mathews et al., 1996)。海 外や国内の一部の地域で既に使用されているが, 価格が高いため,

* 2001 年 4 月 4 日受付 6 月 26 日受理

. 正会員 工博 東北大学講師 大学院工学研究科地球工学専攻

2. 東北大学大学院生 工学研究科地球工学専攻 (現 (株) 新潟鐵工所)

3. 工博 東北電力 (株) 研究開発センター 研究員

4. 正会員 工博 東北大学教授 大学院工学研究科地球工学専攻

5. 正会員 宮城県産業技術総合センター 上席主任研究員

[ 著者連絡先 ] FAX 022-217-7385 (東北大・地球)

キーワード: 酢酸, 超臨界水, 亜臨界水, 湿式酸化, も火殼, 稲わら
一般への普及はあまり進展していない。CMA が高価なのは天然材 料でない原料の酢酸を安価に製造する技術が開発されていないこ とによる。

他方，植物性廃棄物の中では，炭水化物を主成分とする食品廃 棄物のほかに, セルロース系廃棄物も高い排出割合を示している。 植物性食品廃棄物と同様にセルロース系廃棄物からも, 湿式酸化 により酢酸を大量に作れれば, CMA を安価に製造する技術の開発 につながるものと期待される。しかし，セルロース系廃棄物の組 成は炭水化物よりも加水分解しにくいセルロース， ヘミセルロー スおよびリグニンなどから構成されており，湿式酸化により酢酸 を大量に生成できるか否かについては明らかになっていない。そ こで，農業廃棄物であるもみ殼と稲わらを試料として検討するこ ととした。稲わらは収穫時に裁断されてその場で散布されること が多いが、もみ殼はまとまって排出されるものが多く，その量は 全国で $240 \sim 300$ 万 $\mathrm{t}$ と推定されている (廃棄物処理・再資源化技 術ハンドブック，1993)。しかし，現在まで多くの利用法に関する 研究が実施されてきているにもかかわらず，効果の高い画期的な 利用法の開発には至っていない。

また，既報 (金ら，1999，2000) では $400{ }^{\circ} \mathrm{C}$ 以上の温度における 湿式酸化について述べた。これは，もともとの目標を超臨界水湿 式酸化により生ごみを完全酸化分解処理することおよびその発生 熱を水蒸気発電に利用することにおいたためである。しかし，水 の超臨界域では, 装置条件が厳しくなり, 結果としてコストも高 
くなるなどの問題があるため，本研究では反応条件を緩和して， 水の亜臨界温度域の $300{ }^{\circ} \mathrm{C}$ から超臨界温度域の $400{ }^{\circ} \mathrm{C}$ までの温度 範囲を対象とした。

さらに, 水は超臨界状態になると, 密度, 拡散係数, 誘電率, 有機物の溶解度などの性質が大きく変化するので，超臨界状態と 亜臨界状態での反応挙動は臨界点 ( 温度 $647 \mathrm{~K}$, 圧力 $22.1 \mathrm{MPa}$ ) を 境にして大きく異なるといわれている (Shaw et al, 1991; Lee et al, 1990 ; Li et al, 1991)。そこで, $\mathrm{H}_{2} \mathrm{O}_{2}$ を酸化剂とした場合につい て, 水の超臨界および带臨界条件下における湿式酸化反応の相違 の有無についても考察した。

\section{2. 実験試料および実験方法}

\section{$2 \cdot 1$ 実験試料と酸化剂}

もみ殼および稲わらの成分は地域，土壌の種類によって違いは あるが，セルロース，へミセルロース，リグニンなどの繊維が約 $40 \%$ ，炭水化物が約 $30 \%$ であり，無機物としてケイ酸が $16 〜 19$ \%含まれる (廃棄物処理・再資源化技術ハンドブック，1993)。本 研究で試料として取り上げたもみ殼および稲わらはともに宮城県 産のものである。測定した $\mathrm{C}, \mathrm{N}$ 組成および含水率を Table 1 に示 す。元素組成は CNS 分析装置 ((株) Leco 社製, CNS2000)により 測定した。また，もみ殼と稲わらは粉砕して用いた。その粒子径 分布を Table 2 に示す。

酸化剂には過酸化水素水を用いた。酸化剂の供給量については, 試料中の全有機炭素 (TOC) を完全に二酸化炭素に酸化するのに必 要とする理論量を酸素供給率 $100 \%$ と定義した。多糖類を主成分 とする植物性生ごみを完全酸化分解する場合，この酸素供給率が $100 \%$ で酸素は十分であることが分かっている(金ら，1999)。

\section{$2 \cdot 2$ 実験方法}

既報（金ら，2000）と同様に，加熱炉には溶融塩恒温槽を用い， また反応容器にはSUS 316 チューブ製のバッチ式小型反応容器 (内容積約 $5.7 \mathrm{ml}$ ) を用いたが, 既報 (金ら, 2000) の場合とは異な り両端をスウェージロックキャップで直接密閉し，ガス採取用の バルブは取り付けなかった。このため, 反応容器を縦でなく横長 の状態で溶融塩恒温槽に入れ，これを溶融塩恒温槽中で機械的に ゆっくりと振とうさせた。実験手順は基本的に既報 (金ら，2000) と同様であり，その概要は以下のようである。

Table $1 \mathrm{C}, \mathrm{N}$ composition and water content of materials.

\begin{tabular}{lccc}
\hline & $\mathrm{C}$ & $\mathrm{N}$ & Water \\
\hline Rice hull & 37.70 & 0.91 & 8.10 \\
Straw & 38.50 & 1.12 & 7.60 \\
\hline C, N: Dry weight in wt\% & & \\
Water: wt $\%$ & &
\end{tabular}

Table 2 Particle size of rice hull and straw used as starting material.

\begin{tabular}{cc}
\hline Particle size $(\mathrm{mm})$ & Weight $(\%)$ \\
\hline$<0.35$ & 17.4 \\
$0.35 \sim 1.19$ & 81.4 \\
$1.19 \sim 2.00$ & 1.2 \\
\hline
\end{tabular}

Table 3 Experimental conditions.

\begin{tabular}{llcccc}
\hline $\begin{array}{l}\text { Materials* } \\
(\mathrm{g})\end{array}$ & $\begin{array}{l}\text { Temp. } \\
\left({ }^{\circ} \mathrm{C}\right)\end{array}$ & $\begin{array}{c}\text { Time } \\
(\mathrm{min})\end{array}$ & $\begin{array}{c}\text { Oxygen supply } \\
(\%)\end{array}$ & $\begin{array}{c}\text { Pressure } \\
(\mathrm{MPa})\end{array}$ & $\begin{array}{c}\text { Water fill } \\
(\%)\end{array}$ \\
\hline 0.07 & $300-400$ & $1-6$ & $70-150$ & $12-30$ & 30 \\
\hline * Dry weight
\end{tabular}

* Dry weight
反応容器に未乾燥の試料 ( 乾燥重量で $0.07 \mathrm{~g}$ ) を所定濃度の過酸 化水素水とともに入れて素早く密閉した。次に, 反応容器を溶融 塩恒温槽に浸して加熱を行い, 反応を開始させた。所定時間経過 後, 反応容器を溶融塩恒温槽から取り出し, 素早く冷水中に投入 して強制冷却した。なお, 加熱用溶融塩恒温槽の温度を反応温度 とし, 反応時間は反応容器を溶融塩恒温槽に浸したときから取り 出すまでの経過時間とした。水充填率は, 特に示さない限り, 反 応容器の内容積の $30 \%$ とした。実験条件をTable 3にまとめて示す。 冷却後反応容器を開けて, 反応後の溶液を $0.45 \mu \mathrm{m}$ のシリンジ フィルタを用いて固体からろ別・採集した。次に，得られた溶液 中の TOC を測定し, その成分をガスクロマトグラフ質量分析計 (GC/MS), 高速液体クロマトグラフ (HPLC) および核磁気共鳴装置 (NMR) で分析した。これらの分析条件を Table 4 に示す。

\section{3. 結果と考察}

\section{$3 \cdot 1$ もみ殼・稲わらの湿式酸化分解性}

Fig. 1 に, 反応温度 $400{ }^{\circ} \mathrm{C}$, 酸素供給率 $110 \%$ の条件下で, TOC 分解率および残存酢酸濃度に及ぼす反応時間の影響を調べた結果 を示す。ここで, TOC 分解率を次のように定義した。

$$
\mathrm{TOC} \text { 分解率 }(\%)=\frac{\text { 試料の } \mathrm{TOC}-\text { 反応後の液相の } \mathrm{TOC}}{\text { 試料の } \mathrm{TOC}} \times 100
$$

図には, 植物性食品廃棄物の代表として, 人参の場合の結果を 比較のためにあわせて示した。まず, TOC 分解率についてみると, 反応時間 1 分で, TOC 分解率は約 $87 \%$ に達している。すなわち, もみ殼・稲わらは酸化されやすいが, 食品 ( 人参) より残存 TOC は高いことが分かった。一般に湿式酸化反応では，多糖類はまず 加水分解によりヘキソース ( 主にグルコース) やペントースなど の単糖になり, 次に, 単糖類の酸化反応が起こるが, もみ殼・稲 わらには加水分解しにくい繊維が多いため, 残存 TOC が高くなっ たものと考えられる。その後, TOC 分解率は反応時間の増加とと もに増加するが, 反応時間が 2 分以後になると, 変化がほとんど 見られなくなっている。

次に, 酢酸濃度についてみると, 反応時間 1 分で酢酸濃度は $3,500 \sim 4,500 \mathrm{mg} / \mathrm{L}$ となり, 人参の場合より高い。これはもみ殼・

Table 4 Experimental conditions used for GC/MS, HPLC and ${ }^{1} \mathrm{H}-\mathrm{NMR}$ analyses.

\begin{tabular}{|c|c|c|}
\hline \multicolumn{3}{|l|}{ GC/MS } \\
\hline Instrument & \multicolumn{2}{|c|}{$\begin{array}{l}\text { GC: Hewlett Packard } 5890 \text { Series II Plus } \\
\text { MS: Hewlett Packard } 5890 \text { B Series II Plus } \\
\text { Column: HP-INNOWAX (Cross-Linked PEG } 30 \mathrm{~m} \times \\
0.25 \mathrm{~mm} \times 0.25 \mu \mathrm{m} \text { ) }\end{array}$} \\
\hline Flow rate & \multicolumn{2}{|c|}{$0.7 \mathrm{ml} / \mathrm{min}$} \\
\hline Injection temp. & \multicolumn{2}{|c|}{$230^{\circ} \mathrm{C}$} \\
\hline Detection temp. & \multicolumn{2}{|c|}{$250^{\circ} \mathrm{C}$} \\
\hline Oven temp. & \multicolumn{2}{|c|}{$\begin{array}{l}\text { begin at } 40^{\circ} \mathrm{C} \text {, ramped at } 7^{\circ} \mathrm{C} / \mathrm{min} \text { to } 250^{\circ} \mathrm{C} \text {, and } \\
\text { then held for } 20 \text { minutes. }\end{array}$} \\
\hline Injection & \multicolumn{2}{|c|}{ splitless } \\
\hline \multicolumn{3}{|l|}{ HPLC } \\
\hline Instrument & \multicolumn{2}{|c|}{ Waters } \\
\hline Column & \multicolumn{2}{|c|}{ Shodex lonpak KC-811 $\times 1$} \\
\hline Fluent & \multicolumn{2}{|c|}{$1 \mathrm{mM} \mathrm{HClO}_{4}$} \\
\hline Flow rate & \multicolumn{2}{|c|}{$1.0 \mathrm{ml} / \mathrm{min}$} \\
\hline Detector & \multicolumn{2}{|c|}{$\mathrm{UV}-210 \mathrm{~nm}$} \\
\hline Temp. & \multicolumn{2}{|c|}{ Ambient } \\
\hline \multicolumn{3}{|l|}{ NMR } \\
\hline \multirow{2}{*}{\multicolumn{3}{|c|}{$\begin{array}{ll}\text { Instrument } & \text { JEOL JNM-LA300 } \\
\text { Observation frequency } & 300.40 \mathrm{MHz}\end{array}$}} \\
\hline & & \\
\hline \multicolumn{2}{|c|}{$\begin{array}{l}\text { Pulse width } \quad 6.05 \mu \sec \left(\text { obs } 90^{\circ}\right) \\
\text { ) }\end{array}$} & \\
\hline \multicolumn{2}{|l|}{ Pulse delay } & $1.5474 \mathrm{sec}$ \\
\hline & 160 \\
\hline \multicolumn{2}{|c|}{$\begin{array}{l}\text { Accumulation times } \\
\text { Sample temp. }\end{array}$} & $25^{\circ} \mathrm{C}$ \\
\hline \multicolumn{2}{|l|}{ Sample tube } & $5 \mathrm{~mm}$ \\
\hline \multicolumn{2}{|l|}{ Internal standard } & DSS \\
\hline
\end{tabular}



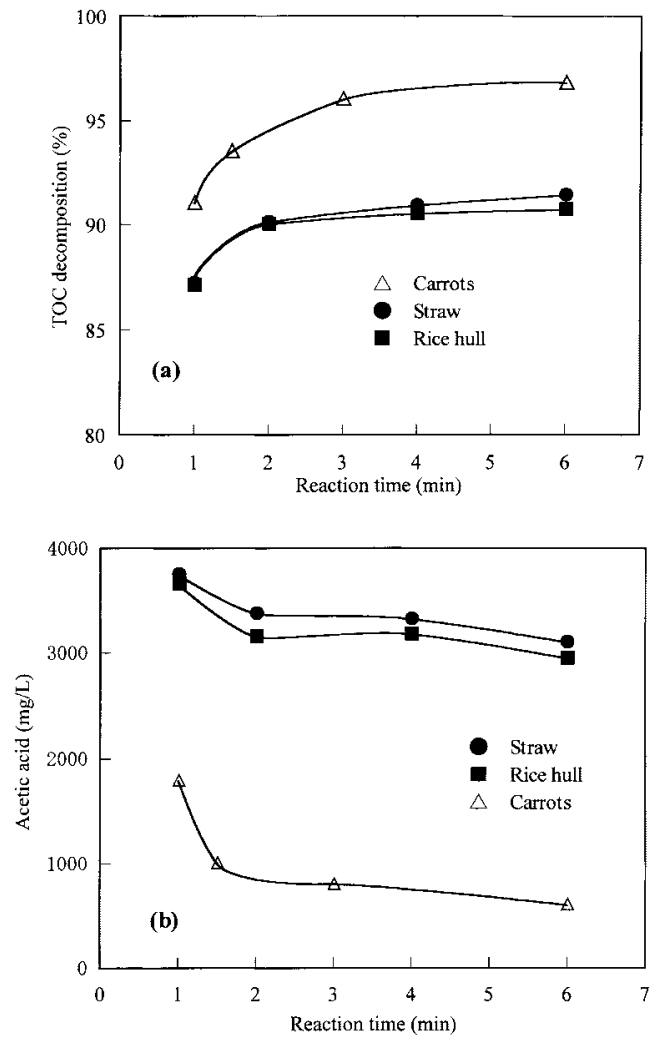

Fig.1 Variation of TOC decomposition and acetic acid concentration with reaction time (reaction temperature : $400{ }^{\circ} \mathrm{C}$, oxygen supply : $110 \%$ for rice hull and straw, $100 \%$ for carrots).

稲わらなどのセルロース系廃棄物の湿式酸化により，酢酸が大量 に得られることを示している。その後, 反応時間の増加により酢 酸濃度は減少するが，2 分以後ではほとんど変化しなくなるとい う傾向がみられる。

2 分以後で, TOC 分解率と酶酸濃度のいずれも変化しなくなる ことについては以下のように考察した。すなわち, Fig.1(b) から分 かるように, 2 分以後での酶酸濃度は約 $3,000 \mathrm{mg} / \mathrm{L}$ で, 炭素量に 換算すると, 2 分以後の残存 TOC とほぼ一致している。すなわち, 反応時間 2 分以後での残存物はほとんどが酶酸である。この酶酸 は難分解であり，分解にはより高い温度が必要であるため，反応 時間 2 分以後の $\mathrm{TOC}$ 分解率と酢酸濃度はほとんど変化しなかった ものと考えられる。

さらに，もみ殼と稲わらを比較すると，反応温度が水の亜臨界女 るいは超臨界のいずれの温度域であっても，もみ殼と稲わらの湿式 酸化による反応性に有意な相違が見られず，同一条件下であれば， 同程度に酢酸が生成されることが分かった。これらの結果により， これ以後は試料をもみ殼に限定し，検討を行うことにした。

\section{$3 \cdot 2$ もみ殼の湿式酸化による酢酸の生成}

$3 \cdot 2 \cdot 1$ 多量に䣷酸を生成させる条件酢酸を利用寸ると いう観点からは，高濃度の酢酸が必要である。既報（金ら，2000） では, 野菜のような食物生ごみの超臨界水湿式酸化により, 酢酸を 選択的に生成させる条件について検討したが，加水分解しにくい繊 維を多量に含むもみ殼・稲わらについては, 加水分解しや寸い炭水 化物を主成分とする食物の場合とは異なることも考えられる。

Fig. 2 に, 酸素供給率を $110 \%$ とした場合の, 酢酸濃度に及ぼす 反応温度と反応時間の影響を示す。全体的にみると, 反応温度の 上昇と反応時間の増加はともに酶酸濃度を減少させるという傾向 が見られる。また，酢酸濃度の減少に及ぼす反応温度と反応時間 の影響を比べると, 反応温度の影響の方が大きい。特に, $350{ }^{\circ} \mathrm{C}$

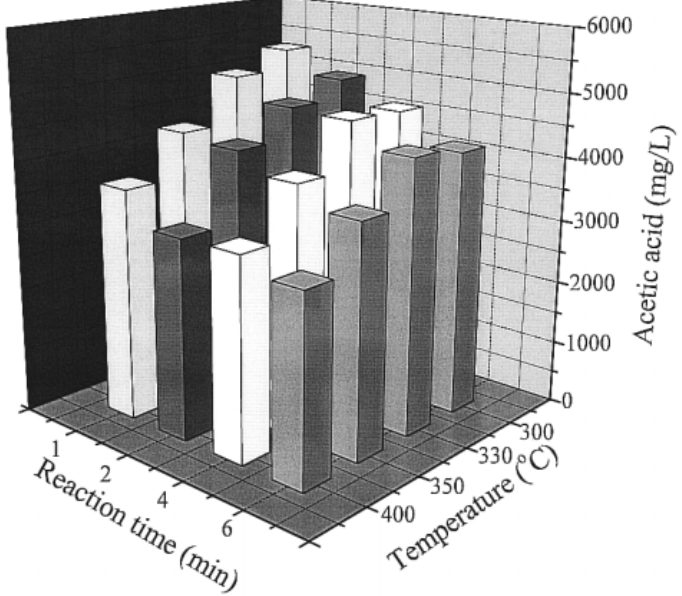

Fig.2 Dependence of acetic acid concentration on reaction time and temperature (oxygen supply : $110 \%$ ).

以上になると，この影響が強く見られている。

さらに, 反応時間が 1 分, 反応温度が $300 \sim 400{ }^{\circ} \mathrm{C}$ の範囲で, 酸素供給率を $70 \sim 150 \%$ の範囲で変化させた場合の, 酢酸濃度に 及ぼす酸素供給率の影響について Fig.3 に示す、、m。全体的な 傾向をみると, 酸素供給率の増加とともに酢酸濃度は減少してい るが，酸素供給率が $110 \%$ 以下の場合は変化が小さく，110\% 以 上になると急激に減少している。この結果は, 過剩な酸素供給に より難分解な䣷酸の酸化分解を促進することができること, 逆に, 酸素供給率が不足の条件下では, 生成した酢酸の分解は進行しに くいため, 多量の酶酸が得られることを示している。

以上の結果から, 短い反応時間 (1 分) で, 低い反応温度 (300〜 $\left.330{ }^{\circ} \mathrm{C}\right)$, 低い酸素供給率 $(70 \sim 110 \%)$ の条件下で, 酢酸が多量に 得られることが分かった。その中で, 最も高い酢酸濃度が得られ る反応条件は, 反応時間 1 分, 反応温度 $300{ }^{\circ} \mathrm{C}$, 酸素供給率 $70 \%$ であった。その酢酸の収率は, 仕込み試料を基準とした炭素と重 量収率に換算してそれぞれ $15.0 \%$ と $14.1 \%$ である。植物性食品生 ごみの場合 (炭素に対する酶酸収率は $16.1 \%$ ) とほぼ同じ程度の酢 酸収率が得られた。また, 前述したように, もみ殼と稲わらの間 には湿式酸化による反応性に相違はない。これらのことから, セ ルロース系廃棄物に関しても, 湿式酸化を行うことで, 植物性食 品生ごみの場合と同程度の転換率で酢酸を生成できることが分 かった。

$3 \cdot 2 \cdot 2$ 酰酸濃度と酢酸純度 反応後の溶液中の䣷酸を利 用する場合，高濃度である上に，さらに酢酸の割合（以下，純度

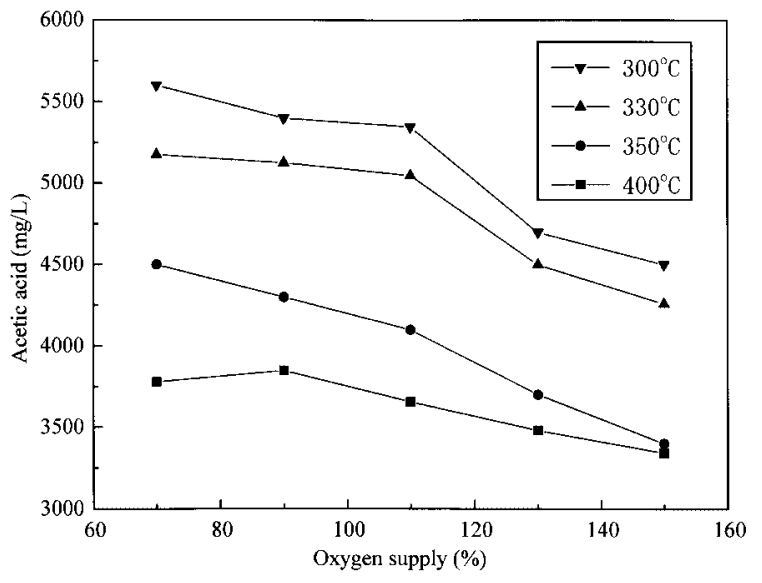

Fig.3 Dependence of acetic acid concentration on oxygen supply (reaction time : $1 \mathrm{~min}$ ) 
と称す）が高いことが望ましい。そこで，高濃度・高純度酢酸が 得られる反応条件について検討した。酶酸純度は次式に示寸よう に, 反応後の溶液中に含まれる酢酸の割合で定義した。

$$
\text { 䣷酸純度 }(\%)=\frac{\text { 反応後の液相中の酷酸の炭素量 }}{\text { 反応後の液相中の全有機炭素量 }} \times 100
$$

Fig.4(a)に, 酸素供給率 $110 \%$, 反応時間 1 分の条件下で, 反応 温度を $300 \sim 400{ }^{\circ} \mathrm{C}$ 範囲で変化させた場合の酶酸純度と䣷酸濃 度を示す。この結果から, 反応温度が $300{ }^{\circ} \mathrm{C} ら 330{ }^{\circ} \mathrm{Cになると,}$ 酢酸純度が急激に増加しているのに対して, 酢酸濃度はそれほど 減少していないことが分かる。また, $330{ }^{\circ} \mathrm{C}$ 以上においては, 酢 酸純度はわずか増加しているものの, 酢酸濃度がかなり減少して しまうことも分かる。さらに, Fig.4(b) に示す酸素供給率を変化さ せた場合の䣷酸純度と酢酸濃度の結果を見ると,酸素供給率が 110 $\%$ になると, 䣷酸純度が急激に増加しているのに対して酢酸濃度 は僅かしか減少していない。また, 酸素供給率が $110 \%$ 以上では, 酢酸純度はほとんど变化しないが, 酢酸濃度は大幅に減少してい る。以上のことを総合的に評価すると, 酢酸が相対的に高濃度・ 高純度で得られる反応条件は, 反応時間 1 分で, 反応温度 $330{ }^{\circ} \mathrm{C}$, 酸素供給率 $110 \%$ であることが分かった。

\section{$3 \cdot 3$ 酶酸以外の有機残存物}

$3 \cdot 3 \cdot 1$ 酶酸以外の有機残存物 以上の結果は, 高濃度・高 純度の䣷酸が得られる条件下においても, 酢酸以外の有機残存物 が約 $30 \%$ も存在していることを示している。

Emanuel(Emanuel, 1965) の湿式酸化反応機構によると, 有機物 は，引き抜かれやすい水素がヒドロキシラジカル等により引き抜 かれることによって反応が開始し，生成したヒドロペルオキシド からアルコールとケトンが生成し，アルコールはまたケトンを経 由して有機酸になる。すなわち, 湿式酸化過程での最終の有機物 はカルボン酸であり, それ以外の有機物は酸化過程の途中にある か未だ酸化されていないものということになる。
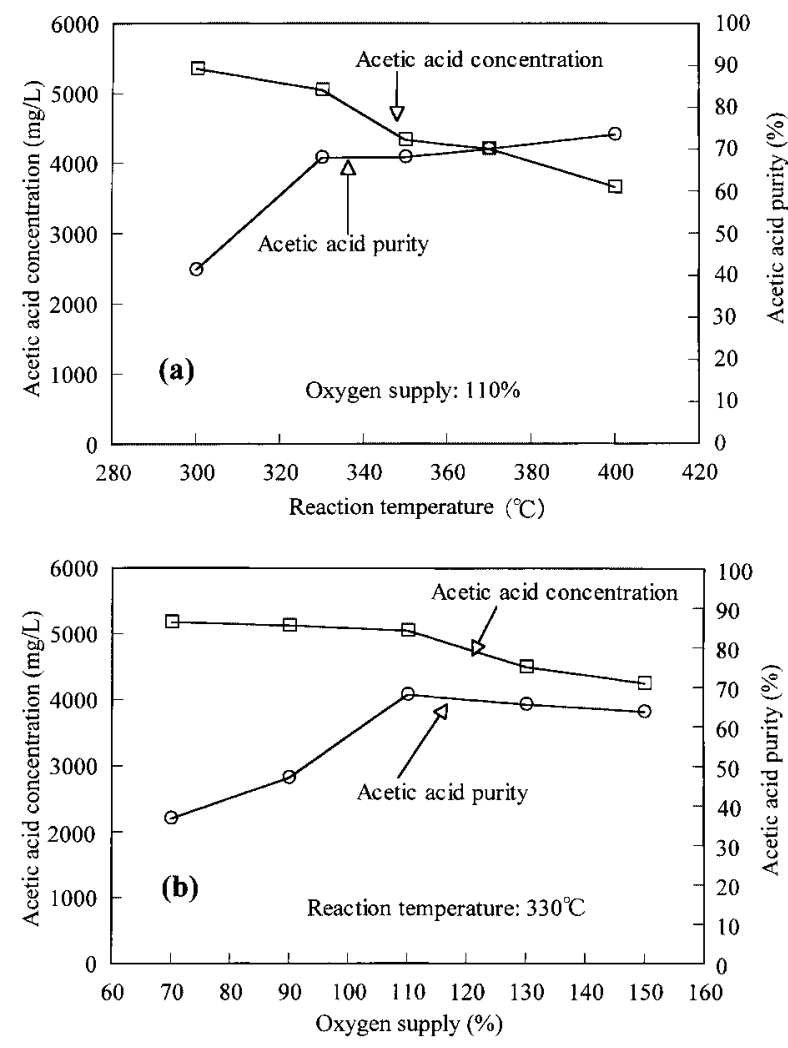

Fig.4 Variation of concentration and purity of acetic acid with reaction temperature (a) and oxygen supply (b) (reaction time : $1 \mathrm{~min}$ ).
Fig.5 は, 反応温度 $300 \sim 400{ }^{\circ} \mathrm{C}$, 反応時間 1 分, 酸素供給率 $110 \%$ の条件下で反応後の液相の HPLC 分析結果である。䣷酸の ほかに, 苳酸, 蟻酸, マレイン酸および琥珀酸などの低級カルボ ン酸が検出されている。Fig.6 に, 反応時間 1 分, 酸素供給率 110 $\%$ で, 反応温度 $300{ }^{\circ} \mathrm{C}, 330{ }^{\circ} \mathrm{C}, 400{ }^{\circ} \mathrm{C}$ 場合の反応後の液相を $\mathrm{GC} / \mathrm{MS}$ により分析した結果を示す。圧倒的に大きい酢酸のピー クのほか, 低級カルボン酸のプロピオン酸と酪酸が検出され, ま た, アセトールと少量のアセトアミドおよびフェノールが検出さ れている。

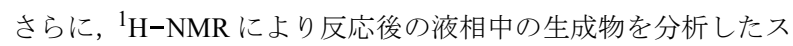
ペクトルを Fig.7 に示す。まず, $2.08 \mathrm{ppm}$ の位置に酶酸のメチル 基 $\left(\mathrm{C}_{3} \mathrm{COOH}\right)$ に帰属される大きなシグナルが見られる。また, そ れぞれ $2.35 \mathrm{ppm}, 2.66 \mathrm{ppm}$ および $8.25 \mathrm{ppm}$ の位置にプロピオン酸

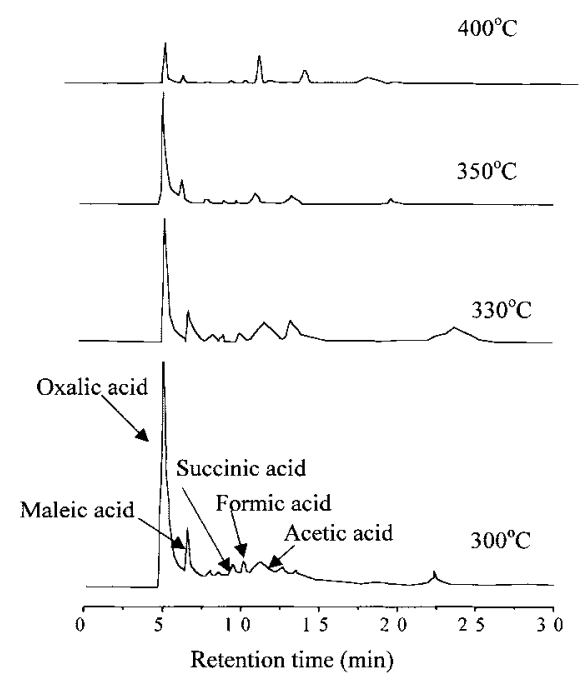

Fig.5 Variation of HPLC chromatograms of intermediate products in the solution after oxidation at $1 \mathrm{~min}$ of reaction time and $110 \%$ of oxygen supply with reaction temperature (UV detection at $210 \mathrm{~nm}$ ).

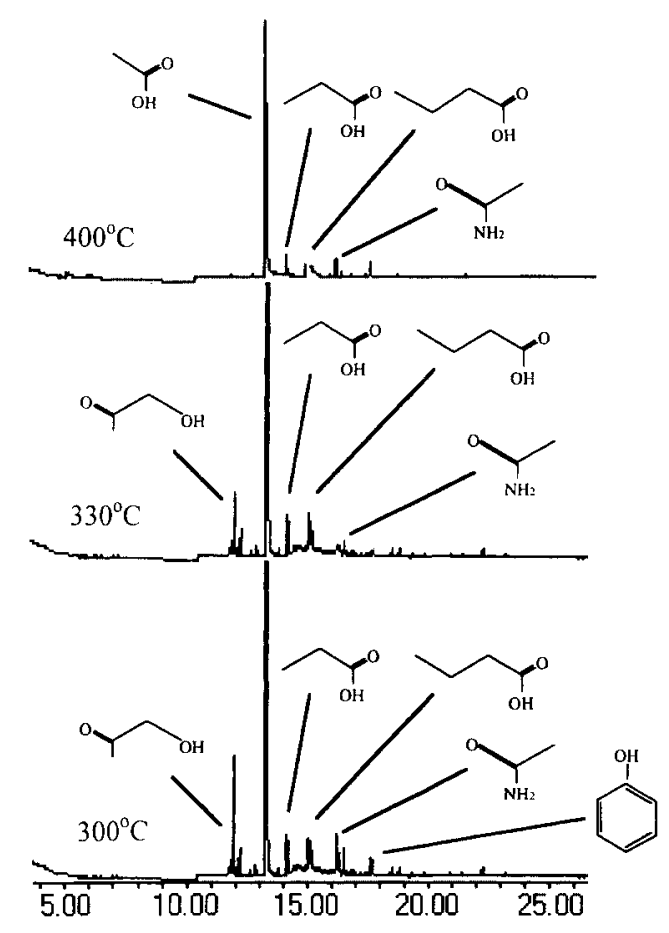

Fig.6 Variation of GC / MS chromatograms of intermediate products in the solution after oxidation at 1 min of reaction time and $110 \%$ oxygen supply with reaction temperature. 


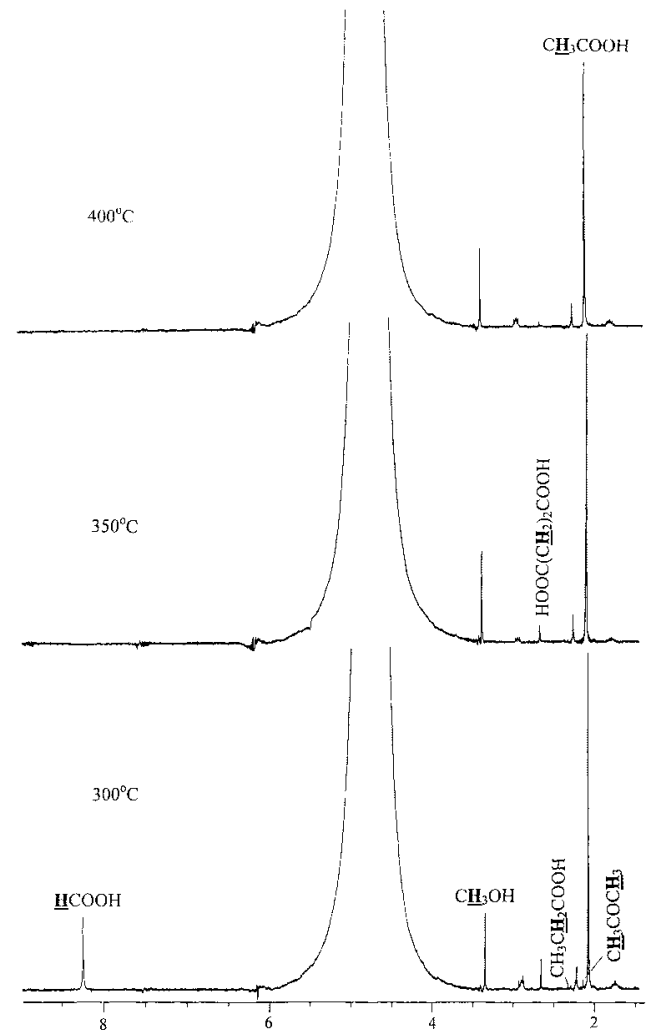

Fig.7 Variation of ${ }^{1} \mathrm{H}-\mathrm{NMR}$ spectra of intermediate products in the solution after oxidation at $1 \mathrm{~min}$ of reaction time and $110 \%$ oxygen supply with reaction temperature.

構造のメチレン基 $\left(\mathrm{CH}_{3} \mathrm{CH}_{2} \mathrm{COOH}\right)$, 琥珀酸構造のメチレン基 $\left(\mathrm{HOOC}\left(\mathrm{CH}_{2}\right)_{2} \mathrm{COOH}\right)$ および蟻酸のプロトンに帰属されるシグナ ルが見られ，酢酸の他に低級カルボン酸の蟻酸，プロピオン酸お よび琥珀酸の存在が確認された。これらの結果は HPLC と GC/MS の分析結果と一致している。また, $2.14 \mathrm{ppm}, 3.35 \mathrm{ppm}$ の位置に, それぞれケトン構造のメチル基 $\left(\mathrm{CH}_{3} \mathrm{COCH}_{3}\right)$ とメタノール構造の メチル基 $\left(\mathrm{CH}_{3} \mathrm{OH}\right)$ に帰属されるシグナルが見られている。

これらの結果から, 酢酸以外の有機残存物として多くのものが 残存しており，その中でメタノールも少なくないが，最も多いの は低級カルボン酸類であることが分かった。この結果は，上記の Emanuel の機構に沿ったものである。

そこで, HPLC により Fig.5 に示す䣷酸以外の低級カルボン酸の 定量分析を行った。この結果を Fig.8 示す。Fig.8(a)に示すように,
酢酸以外の有機残存物中での低級カルボン酸類の割合は高く，高 い酰酸濃度が得られる条件下で, 酢酸以外の残存物の約 $1 / 2$ を占 めている。さらに, Fig.8(b) に示すそれぞれの低級カルボン酸の濃 度についてみると, これらの低級カルボン酸の中では葆酸が最も 多く, 次が蟻酸で, 琥珀酸とマレイン酸は僅かであることが分かっ た。一般に, カルボン酸の酸化分解は, より炭素数の少ないカル ボン酸へと変化する機構で進行し, ジカルボン酸では蓚酸が，モ ノカルボン酸では酢酸と蟻酸が最終のカルボン酸である。なお, これらのカルボン酸のうち酢酸は, カルボニル炭素にメチル基が 結合しているため，もっとも酸化分解されにくい。

\section{$3 \cdot 3 \cdot 2$ 酢酸以外の低級カルボン酸の酸化による酢酸の生成}

酢酸以外の残存物中で高い割合を占める低級カルボン酸類をさ らに酸化を進めることにより䣷酸を生成できれば, 酢酸収率の向上 が期待できることになる。まず，これらの低級カルボン酸中で高い 割合を占める蓚酸と蟻酸については, 上述のように, 酸化されると 直接に $\mathrm{CO}_{2}$ と $\mathrm{H}_{2} \mathrm{O}$ になることが知られている。ここで, 葆酸につ いて, 反応温度 $400{ }^{\circ} \mathrm{C}$, 反応時間 30 秒, 酸素供給率 $100 \%$ の条件 下で確認実験を行った。その結果, 反応後の液相中に䣷酸は検出さ れず, 残存 TOC も検出限界以下であった。次に, 琥珀酸とマレイ ン酸について, 試薬の琥珀酸とマレイン酸を用い, 反応温度 $300{ }^{\circ} \mathrm{C}$, 反応時間 1 分, 酸素供給率 $100 \%$ の条件下で実験を行った。その結 果, 蟻酸と蓚酸のほか, 酢酸も検出された。このことから, 琥珀酸 とマレイン酸は酸化により酢酸を生成することが分かった。しか し, 前述したように, 琥珀酸とマレイン酸の残存濃度がいずれの反 応条件においても非常に低いので, これによる酶酸の生成量の増加 は少いと思われる。また, プロピオン酸, 酪酸は, Williams et al (Williams et al, 1975) と Day et al (Day et al, 1973) が報告しているよ うに, 酢酸を生成する。しかし, Fig.6 に示すように, この 2 つの 酸のピークは小さく, また, Fig.7 に示す ${ }^{1} \mathrm{H}-\mathrm{NMR}$ の分析結果にお いてプロピオン酸はわずかに検出されているが, 酪酸は検出されて いないことから, プロピオン酸と酪酸の残存濃度も低く, これらか らの䣷酸の生成は少ないことが推定される。

これらの結果から, 酢酸以外の低級カルボン酸中で酶酸を生成す る低級カルボン酸の残存濃度は低く, これに対して酢酸を生成しな い蓚酸と蟻酸が多いので，も文殼・稲わらの湿式酸化で酢酸収率を さらに向上させることは，現状では困難であることが分かった。

$3 \cdot 3 \cdot 3$ 酶酸以外の低級カルボン酸の酸化分解性 酢酸以 外の有機残存物の中で低級カルボン酸類の割合は高く，それらの 酸化分解性は酶酸純度に大きな影響を与えると考えられる。

まず, 反応温度の影響についてみると, Fig.9に示すように, こ

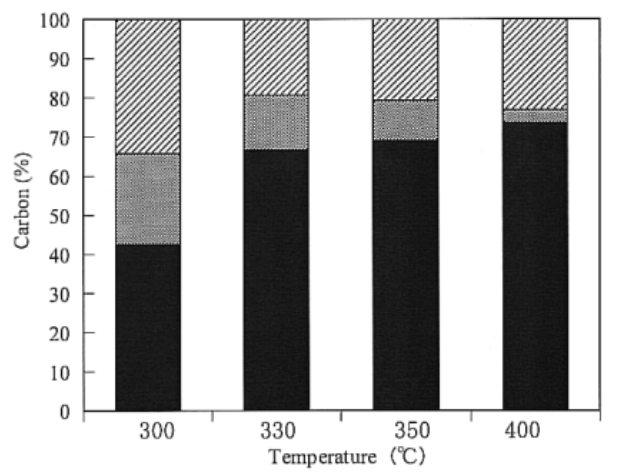

(a)

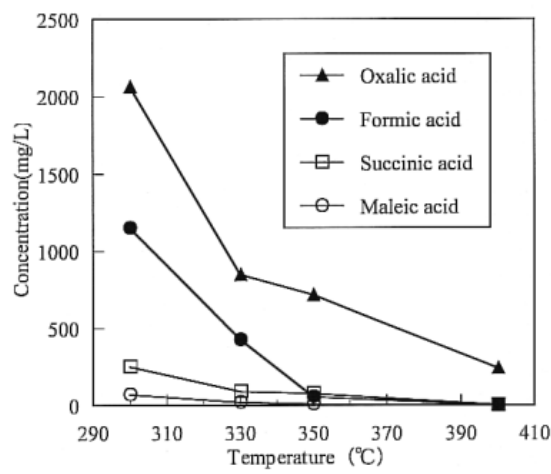

(b)

Acetic acid

Other residual products

Low molecular weight carboxy lic acids excluding acetic acid

Fig.8 Variation of acetic acid, low molecular weight carboxylic acids excluding acetic acid and other residual products with reaction temperature (oxygen supply : $110 \%$ ). 

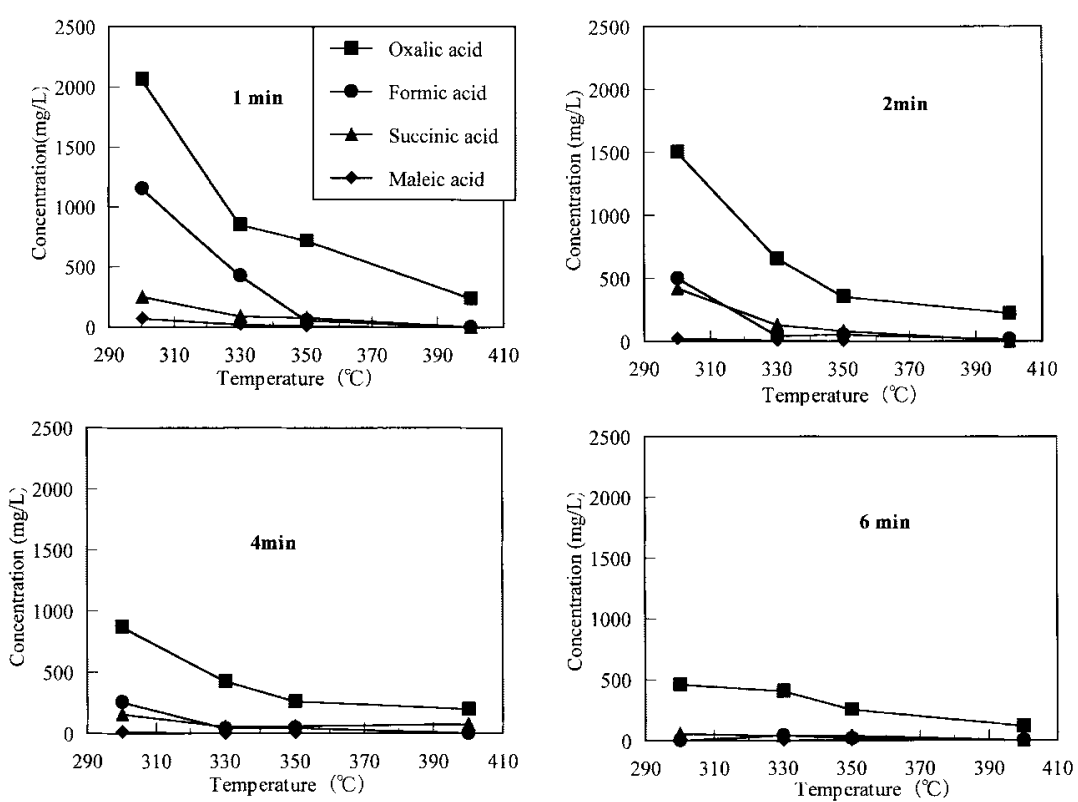

Fig.9 Effect of reaction temperature and reaction time on the concentration of oxalic acid, formic acid, succinic acid and maleic acid (oxygen supply : $110 \%$ ).

れらの低級カルボン酸の濃度は, 反応温度が高くなるにつれて全 体的に減少していることが分かる。特に反応温度が $350{ }^{\circ} \mathrm{C}$ 以上で は, 蓚酸以外の低級カルボン酸はほとんど残存していない。次に, 反応時間の影響についてみると, 反応時間の増加とともにこれら の低級カルボン酸の濃度が減少していることが分かる。特に, こ の影響は温度の低いところで強く見られる。例えば, 反応時間が 6 分になると, $300{ }^{\circ} \mathrm{C}$ にいても, 蓚酸以外の低級カルボン酸はほ とんどなくなっている。このことから，これらの低級カルボン酸 は分解しやすく, 低い反応温度においても, 反応時間の延長によっ て分解されることが分かった。また, Fig.10 に示寸酸素供給率の 影響についてみると, これらの低級カルボン酸は酸素供給率の増 加とともに減少していることが分かる。この結果を Fig. 3 に示寸酢 酸の場合と比較すると, 酸素供給率が $110 \%$ 以下の場合において, 蟻酸や蓚酸の分解が進行しているのに対して酶酸はほとんど減少 していない。これは, 酸素供給率が $110 \%$ 以下のように中間生成 物の分解に要する酸素の供給が不足する状態で酢酸は安定である ため, より分解しやすい蟻酸や蓚酸に酸素が消費され, それらの 分解がより進行したためと考えられる。

次に, 酢酸以外の低級カルボン酸の有機炭素について, 反応後

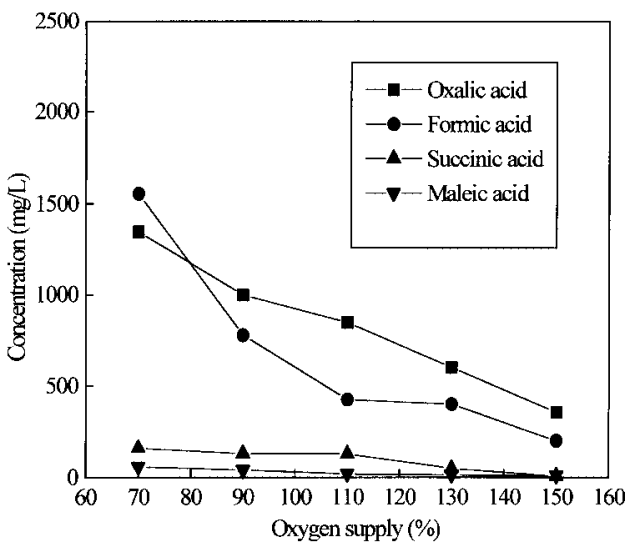

Fig.10 Effect of oxygen supply on concentration of oxalic acid, formic acid, succinic acid and maleic acid (reaction time : $1 \mathrm{~min}$, reaction temperature : $330{ }^{\circ} \mathrm{C}$ ).
の液相残存 TOC 中での割合をみると, Fig.11に示すように, 反応 温度と反応時間の増加とともに, 䣷酸以外の低級カルボン酸は残 存 TOC 中に占める割合を減少させ, 酢酸との割合およびその他の 残存物との割合のいずれでも減少しているということが認められ た。これは, 酶酸以外の低級カルボン酸は, 酢酸より分解しや寸 いだけでなく, 他の残存有機物よりも分解しや寸いことを示して

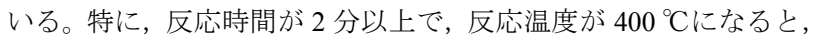
酢酸以外の低級カルボン酸の割合が急に減少し, 酢酸純度は $80 \%$ 以上になった。

これらの結果から, 高濃度酢酸が得られる条件下で, 酢酸以外 の残存物中での低級カルボン酸類の割合は高いが, これらの低級 カルボン酸は䣷酸よりはるかに酸化されや寸いため, 反応時間ま たは反応温度の増加により, 酢酸純度が容易に上がることが分 かった。また, 酢酸純度をさらに上げるためには, カルボン酸以 外の中間生成物の生成・分解条件について検討することが必要で あることが分かった。

\section{$3 \cdot 4$ 水の超臨界域および亜臨界域におけるもみ殼の湿式酸化 反応の相違}

高温高圧水の反応場としての性質は圧力あるいは水密度によっ て変化するが, 本研究の場合のような水充填率を $30 \%$ で一定とし たような条件下では, 超臨界域と亜臨界域は反応場として異なっ ていると考えられることが多い。そこで, 本研究の結果の温度依 存性の連続・非連続の観点からこの点について考察してみた。

まず，中間生成物から水の超臨界および亜臨界域におけるもみ 殼の湿式酸化反応の相違についてみると, Fig.5 と Fig.6 に示す GC / MS, HPLC の分析結果から分かるように, 反応温度が水の亜臨 界もしくは超臨界のいずれの温度域であっても, 検出された中間 生成物は基本的に同じである。また, これらの中間生成物は, 亜 臨界温度域の $300{ }^{\circ} \mathrm{C}$ から超臨界温度域の $400{ }^{\circ} \mathrm{C}$ まで上昇するに従 い次第に減少するが，異常な変化は見られない。

また, Fig.7 に示す ${ }^{1} \mathrm{H}-\mathrm{NMR}$ の分析結果についてみると, 酢酸, 蟻酸, プロピオン酸, 琥珀酸, メタノールおよびケトンにそれぞ れ帰属されるシグナルは, 反応温度の上昇により, このうち蟻酸,

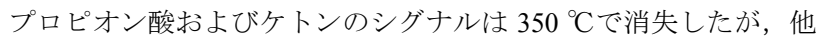
のシグナルは次第に減少しており, これらに異常な変化は見られ 

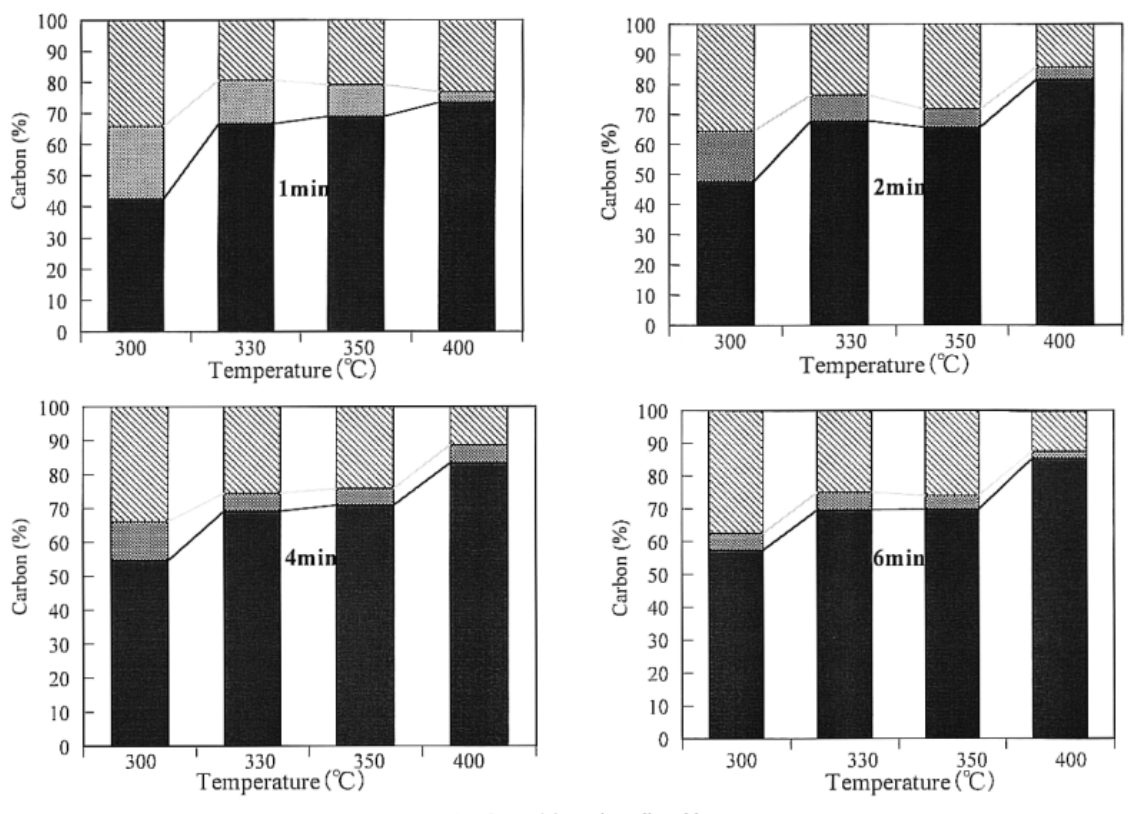

Acetic acid

Low molecular weight
excluding acetic acid

Other residual products

Fig.11 Dependence of TOC of acetic acid, low molecular weight carboxylic acid and other residual products on reaction temperature and time (oxygen supply : $110 \%$ ).

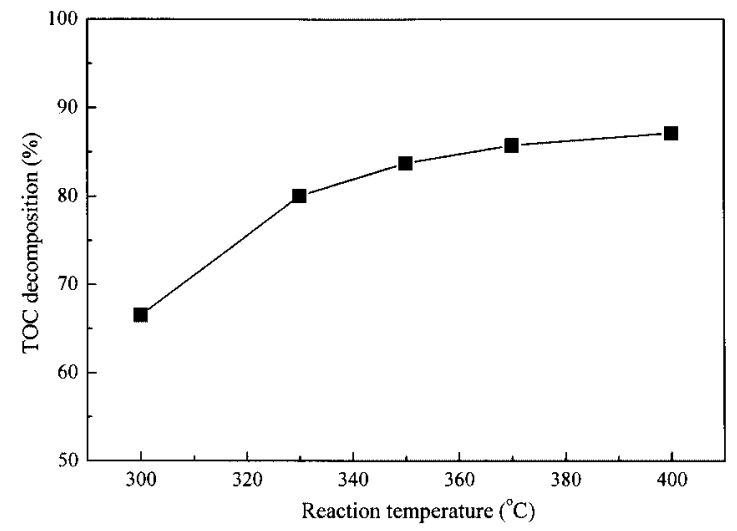

Fig.12 Dependence of TOC decomposition on reaction temperature (reaction time : 1 min, oxygen supply : $110 \%$ ).

ていない。350 ㄷでの蟻酸, プロピオン酸およびケトンのシグナ ルの消失については, Fig.5 と Fig.6 に示すように, $350{ }^{\circ} \mathrm{C}$ 以上に なると，その濃度が非常に低くなっているため検出されなかった ことによると考えられる。

さらに, TOC 分解率の変化を見ると, Fig.12 に示すように, 反応 時間 1 分, 酸素供給率 $110 \%$ の条件下で, 反応温度 $300 \sim 400{ }^{\circ} \mathrm{C} の$ 範囲で変化させて得られた TOC 分解率は, 同様に反応温度の上昇 により，連続的に増加し，急激的で異常な変化は見られていない。

以上の結果から, 反応温度が水の亜臨界もしくは超臨界のいず れの温度域であっても, 中間生成物は基本的に同じであった。ま た, 中間生成物の濃度と TOC 分解率も単調に変化し, 臨界点をは さんで異常な変化は見られなかった。

\section{4. 結 論}

本研究では, 水の超臨界域および亜臨界域において, もみ殼・ 稲わらの湿式酸化分解性と酢酸を大量に生成させる反応条件につ いて調べた。次に, 酶酸以外の残存物の中で高い割合を示寸低級 カルボン酸類の酸化経路の解明により, 酶酸収率の向上の可能性,
およびこれらの低級カルボン酸の酸化分解による酢酸純度への影 響について検討した。

さらに，水の超臨界域および带臨界域の反応場としての湿式酸 化反応における相違の有無についても考察した。これらの結果を 以下にまとめる。

1）もみ殼・稲わらの湿式酸化において, 反応条件を制御する ことによって, 植物性食品生ごみの湿式酸化の場合とほぼ同じ程 度の䣷酸収率が得られる。

2）もみ殼の湿式酸化の場合, 酶酸以外の有機残存物中で低級 カルボン酸類が高い割合を占めている。これらの低級カルボン酸 類には酢酸を生成しない蓚酸と蟻酸が多いので, これらのさらな る酸化による酢酸収率の向上は困難である。しかし, これらの低 級カルボン酸は酸化されや寸いため, 反応時間と反応温度の増加 により，酢酸純度を上昇させることは可能である。

3）中間生成物と TOC 分解率のどちらについても, 臨界点を境 にした異常な変化は見られなかった。

\section{引用 文 献}

Emanuel,. (1965): The Oxidation of Hydrocarbons in the Liquid Phase, Pergamon Press, p. 1

Chollar, B. H. (1984) : Public Roads, Vol. 47, p. 113

Day, D. C, Hudgins, R. R. and Silveston, P. L. (1973) : The Canadian Journal of Chemical Engineering, Vol. 51, p. 733

Gekas, V. and Zhang, W. (1989) : Process Biochemistry, Vol. 24, p. 159

今村成一郎 (1983) : 水処理技術, Vol. 24, p. 93-108

廃棄物処理・再資源化技術ハンドブック編集委員会 (1993) : 廃棄物処理・再資源化技 術ハンドブック, p. 367，建設産業調査会

金 放鳴・木下 睦・榎本兵治 (1999)：廃衰物学会誌，Vol. 10, p. 257-266

金 放鳴・ 木下 睦・守谷武彦・榎本兵治・佐藤尚洋 (2000) : 資源と素材, Vol. 116, p. $265-271$

金 放鳴・ 木下 睦 - 守谷武彦・榎本兵治・佐藤尚洋 (2000) : 資源と素材, Vol. 116, p. $273-278$

Lee, D. S. and Gloyna E. F. (1990) : The Journal of Supercritical Fluids, Vol. 3, p. 249 Li, L., Chen, P. and Gloyna, E. F. (1991) : AIChE J., Vol. 37, p. 1687

Mathews, A. P., Choi, C.H. and Dwyer, S. (1996), J. Environ, Sci. Health, A No. 31, p. 101

Mathews, A. P., Choi, C.H. and Dwyer, S. (1996), J. Environ, Sci. Health, A No. 31, p. 101
農業漁村分化協会 (1987) : 農業技術大系, 土壤施肥編, 7- (1). (2) 各種肥料・飼料 の特性と利用, 第一刷発行

Shaw, R. W., Brill, T. B., Clifford, A. A., Eckert, C. A. and Franck, E. U. (1991) : Chemical \& Engineering, Vol. 23, p. 26

Williams, R. E. L, Silveston, P. L and Hudgins, R. R. (1975) : The Canadian Journal of Chemical Engineering, Vol. 53, p. 354 